\title{
STAT Inhibitor OPB-111077
}

National Cancer Institute

\section{Source}

National Cancer Institute. STAT Inhibitor OPB-111077. NCI Thesaurus. Code C116873.

An orally bioavailable inhibitor of one or more signal transducer and activator of transcription (STAT) protein(s), with potential antineoplastic activity. Upon oral administration, OPB-111077 binds to and inhibits the phosphorylation of STATs. This prevents binding of STATs to DNA sequences on a variety of STAT-responsive gene promoters, which may result in the inhibition of both STAT-mediated transcription and tumor cell proliferation. STATs are constitutively activated in a variety of cancers and play a key role in tumor cell proliferation. 